\title{
Assessment of the osteoblastic cell response to a zinc glass reinforced hydroxyapatite composite (Zn-GRHA)
}

\author{
N. Sooraj Hussain \\ INESC Porto, Rua do Campo Alegre 687, \\ 4169-007 Porto, Portugal \\ and \\ Departamento de Física, Faculdade de Ciências, Universidade do Porto, \\ Rua do Campo Alegre 687, \\ 4169-007 Porto, Portugal \\ E-mail: nandyala.sooraj@fc.up.pt
}

\section{P.S. Gomes and M.H. Fernandes}

Faculdade de Medicina Dentária, Universidade do Porto, Rua Dr. Manuel Pereira da Silva, 4200-393 Porto, Portugal E-mail: pedro.s.gomes@gmail.com E-mail: mhrf@portugalmail.pt

\section{M.A. Lopes and J.D. Santos*}

Departamento de Engenharia Metalúrgica e Materiais, Faculdade de Engenharia, Universidade do Porto, Rua Dr. Roberto Frias, 4200-465 Porto, Portugal and Departamento de Engenharia Mecânica,

CEMUC-Centro de Engenharia Mecânica da Universidade de Coimbra, Pinhal de Marrocos 3030 Coimbra, Portugal

E-mail: malopes@fe.up.pt_ E-mail:jdsantos@fe.up.pt

*Corresponding author

\begin{abstract}
Hydroxyapatite (HA), $\mathrm{Ca}_{10}\left(\mathrm{PO}_{4}\right)_{6}(\mathrm{OH})_{2}$ and tricalcium phosphate (TCP) bioceramics have been used as graft materials. However, optimal biological performance has not been established yet and zinc, being a biosafe, biocompatible element, could favour for specific osteoblastic cell response. Therefore, this paper investigates the preliminary results and potential impact of zinc glass reinforced hydroxyapatite (Zn-GRHA) on a human osteoblastic cell system. The biological behaviour of Zn-GRHA samples was assessed by confocal laser scanning microscopy, while material characterisation was performed by SEM-EDX and XRD analysis. Established cultures reported an increased proliferation and a confluent cell layer in some areas of the material surface at day two. Cells were spread all over the material surface and established multiple cell-to-cell interactions relying on prominent cytoplasmic processes. At day six, confluent cell layers were verified on the Zn-GRHA material's surface, reporting an improved biological response, compared to control (hydroxyapatite).
\end{abstract}


Keywords: zinc glass-reinforced hydroxyapatite; Zn-GRHA; cell proliferation.

Reference to this paper should be made as follows: Sooraj Hussain, N., Gomes, P.S., Fernandes, M.H., Lopes, M.A. and Santos, J.D. (2009) 'Assessment of the osteoblastic cell response to a zinc glass reinforced hydroxyapatite composite (Zn-GRHA)', Int. J. Nano and Biomaterials, Vol. 2, Nos. 1/2/3/4/5, pp.100-109.

Biographical notes: N. Sooraj Hussain is working as an Auxiliary Investigator in the INESC Porto/Department of Physics, Faculty of Sciences, University of Porto, Portugal. He is studying different glassy materials for bone regenerative applications and different laser optical glasses for scientific and technological applications. So far, he published several papers in the international scientific journals.

P.S. Gomes is a DDS and a Lecturer of Immunology. He is a Researcher of the Laboratory of Pharmacology and Cellular Biocompatibility of the Faculty of Dental Medicine, University of Porto, Portugal. His research interests include the evaluation of biomaterials' biocompatibility, namely in which refers to bone regeneration using in vitro human cell culture and in vivo human animal experimentation.

M.H. Fernandes is a Full Professor of Pharmacology and responsible for the Laboratory of Pharmacology and Cellular Biocompatibility of the Faculty of Dental Medicine, University of Porto, Portugal. Her research interests include bone tissue regeneration and cell-based tissue engineering therapies. She has co-authored around 60 publications in international refereed journals.

M.A. Lopes has been a Lecturer in the Materials Section of the Department of Metallurgical and Materials Engineering at University of Porto (FEUP-UP) since 2000, Pedagogical Responsible of the Master in Materials Science at FEUP-UP since February 2003 and Head of the Materials Section of the Department of Metallurgical and Materials Engineering at FEUP-UP since February 2006. She has developed her research in biomaterials at INEB - since 1995 and got her $\mathrm{PhD}$ in 1999 in bone regeneration subject. In tissue-regeneration field, she has been involved in seven research projects and seven post-graduation supervisions and has published 50 international scientific papers in SCI journals.

José Domingos Santos is Associate Professor with Aggregation at FEUP-Faculty of Engineering, University of Porto (2005-present) and is presently Researcher of CEMUC - Centro de Engenharia Mecânica da Universidade de Coimbra. He has actively participated in 12 research projects financed by national and international institutions and was the Scientific responsible of seven. $\mathrm{He}$ is the co-inventor of four registered international patents in the biomaterials field which has resulted in very important trademarks. He has supervised 17 post-graduation projects, including seven post-doctoral researchers (four concluded), $14 \mathrm{PhD}$ with seven concluded and one MSc concluded. He has published 110 scientific publications in international scientific reviews of SCI - Science Citation Index. 


\section{Introduction}

Zinc oxide $(\mathrm{ZnO})$ is a bio-safe, biocompatible material for biomedical applications (Wang, 2004). Zinc has been considered to be an essential mineral for animals and humans since mid-20th century. It is known to be an essential trace element for ossification, fetal growth and development (Spadaro et al., 1970; Prasad, 1998; Salih et al., 2007; Uckan et al., 2001). Zinc deficiency affects cell-mediated immunity and leads to activation of monocytes-macrophages; in addition, this element may play an important role as an antioxidant (Prasad, 1998, 2000; Prasad et al., 2004). Hydroxyapatite (HA), $\mathrm{Ca}_{10}\left(\mathrm{PO}_{4}\right)_{6}(\mathrm{OH})_{2}$ and tricalcium phosphate (TCP) bioceramics have been used as graft materials in vivo and they interact directly with bone (Walsh et al., 2008; Hing et al., 2007; Okuda et al., 2007; Weinand et al., 2006; Caria et al., 2007; Sopyan et al., 2007; Rush, 2005; Silva et al., 2005; Fujita et al., 2003). However, synthetic HA does not contain all the ions found in natural bone nor does it exhibits all the characteristics of living bone. In order to modify the HA, incorporation of bivalent cation $\mathrm{Zn}^{2+}$ could be favourable for bone repair. Zinc containing HA enhanced the osteogenesis and osteoconduction on a critical size defect in the rat calvaria (Clasans-Maia et al., 2008) and stimulatory effect of zinc-releasing calcium phosphate implant on bone formation in rabbit femora has been reported (Kawamura et al., 2002). It has also been shown that zinc doped HA improves osteoblast cell adhesion compared to undoped HA (Webster et al., 2002). Finally, zinc can also have useful antibacterial effects and it follows that zinc can be used to boost the integration of bone grafts in injury sites as well as prevent the infection risks that can arise from these procedures (Osinaga et al., 2003; Bright et al., 2002).

Literature reports on different types of synthesis methods for the production of Zn-HA materials (Jaroch and Clupper, 2007; Fujii et al., 2006; Otsuka et al., 2000). The authors previously reported a liquid phase sintering route using $\mathrm{ZnO}-\mathrm{P}_{2} \mathrm{O}_{5}-\mathrm{CaO}-\mathrm{Na}_{2} \mathrm{O}-\mathrm{CaF}_{2}$ glass in an $\mathrm{HA}$ matrix. Earlier, the authors have studied $\mathrm{CaO}-\mathrm{P}_{2} \mathrm{O}_{5}-\mathrm{Na}_{2} \mathrm{O}-\mathrm{CaO}-\mathrm{CaF}_{2}$ host glass reinforced $\mathrm{HA}$ without $\mathrm{ZnO}$ and registered/patented it as Bonelike ${ }^{\circledR}$. Bonelike ${ }^{\circledR}$ is an osteoconductive synthetic graft material for the enhancement of ossification in biomedical applications and has been extensively reported (Santos et al., 1995, 1999; Knowles et al., 1996; Hussain et al., 2007; Gutierres et al., 2007, 2008).

Therefore, this paper investigates the preliminary results and potential impact of zinc doped glass reinforced hydroxyapatite (Zn-GRHA) in osteoblastic function.

\section{Materials and methods}

\subsection{Preparation of $\mathrm{ZnO}$ glass}

A $\mathrm{ZnO}$ based glass with a chemical composition of $10 \mathrm{ZnO}-60 \mathrm{P}_{2} \mathrm{O}_{5}-15 \mathrm{CaO}-5 \mathrm{Na}_{2} \mathrm{O}-$ $10 \mathrm{CaF}_{2}(\% \mathrm{~mol})$ has been prepared by melting the following mixtures of analytical grade $\mathrm{ZnO}, \mathrm{P}_{2} \mathrm{O}_{5}, \mathrm{CaHPO}_{4}, \mathrm{Na}_{2} \mathrm{CO}_{3}$ and $\mathrm{CaF}_{2}$ raw materials (Sigma Aldrich 99.99\%) in a Pt crucible for about an hour in an electrical furnace at $1450^{\circ} \mathrm{C}$. By employing the conventional method and then finally using standard crushing and sieving techniques, a powder with less than 75 micron size was obtained. 


\subsection{Preparation of $H A$}

$\mathrm{HA}, \mathrm{Ca}_{10}\left(\mathrm{PO}_{4}\right)_{6}(\mathrm{OH})_{2}$ has been prepared with the following chemical reaction: $10 \mathrm{Ca}(\mathrm{OH})_{2}+6 \mathrm{H}_{3} \mathrm{PO}_{4} \rightarrow \mathrm{Ca}_{10}\left(\mathrm{PO}_{4}\right)_{6}(\mathrm{OH})_{2}+18 \mathrm{H}_{2} \mathrm{O}$.

Briefly, appropriate quantities of analytical grade calcium hydroxide, $\mathrm{Ca}\left(\mathrm{OH}_{2}\right)$ and ortho phosphoric acid, $\mathrm{H}_{3} \mathrm{PO}_{4}$ have been mixed independently with deionised water. Then $\mathrm{Ca}\left(\mathrm{OH}_{2}\right)$ solution was transferred into $\mathrm{H}_{3} \mathrm{PO}_{4}$ solution for about four hours with constant mixing (100 rpm) maintaining the $\mathrm{pH} 10.50$, at the end. After 24 hours, the material was filtered to remove the excess water and then dried at $60^{\circ} \mathrm{C}$ for approximately 48 hours. Finally, the dried product was crushed and sieved for less than 75 micron size particles. HA disks where prepared by uni-axial pressing technique.

\subsection{Preparation of $\mathrm{Zn}$-GRHA composite}

The Zn-GRHA composite was obtained by mixing $2.5 \%$ of glass with HA in isopropanol. The obtained composite was dried at $60^{\circ} \mathrm{C}$ and then sintered at $1300^{\circ} \mathrm{C}$ for one hour and finally using standard crushing and sieving techniques, the authors prepared few discs for cell culture studies by uni-axial pressing technique. Prior to cell seeding, HA and $\mathrm{Zn}$-GRHA discs were sterilised in a steam autoclave at $120^{\circ} \mathrm{C}$ for 30 minutes.

\subsection{Materials characterisation}

X-ray diffraction (XRD) was performed on powder samples of glass, Zn-GRHA and HA by using Siemens D 5000 diffractometer with $\mathrm{Cu}-\mathrm{K}_{\alpha}$ radiation $(\lambda=1.5418 \AA)$. The scans were made in the range of $25-40^{\circ}(2 \theta)$ with a step size of $0.02^{\circ}$ and a count time of $2 \mathrm{sec} / \mathrm{step}$. A scanning electron microscopy (JEOL JSM 630IF) equipped with an energy dispersive analyzer (SEM/EDS technique) was used to evaluate the microstructure of these samples.

\subsection{Cell culture studies}

MG63 cells, human osteosarcoma-derived osteoblastic cells, were cultured in $\alpha$-minimal essential medium supplemented with $10 \%$ foetal bovine serum, ascorbic acid $\left(50 \mu \mathrm{g} \cdot \mathrm{ml}^{-1}\right)$, penicillin-streptomicin $\left(100 \mathrm{IU} \cdot \mathrm{ml}^{-1}\right.$ and $10 \mathrm{mg} \cdot \mathrm{ml}^{-1}$, respectively) and fungisone $\left(2.5 \mu \mathrm{g} \cdot \mathrm{ml}^{-1}\right)$, at $37^{\circ} \mathrm{C}$, in a humidified atmosphere of $5 \% \mathrm{CO}_{2}$ in air, in $50 \mathrm{~cm}^{2}$ flasks. The medium was changed twice a week until sub-confluence. For materials' seeding, adherent cells were enzymatically released ( $0.05 \%$ trypsin- $0.25 \%$ EDTA) and resuspended in complete medium. Cells were cultured at a density of $10^{4}$ cells. $\mathrm{cm}^{-2}$, for six days on the surface of HA and Zn-GRHA discs, that had been previously immersed in complete culture medium for one hour. Seeded material samples were evaluated throughout the incubation time, at days two and six, for cell morphology and cell growth, by confocal laser scanning microscopy (CLSM).

At days two and six, the colonised HA and Zn-GRHA discs were fixed in 3.7\% methanol-free formaldehyde and permeabilised with $0.1 \%$ Triton $^{\circledR}$. Cell cytoskeleton filamentous actin (F-actin) was visualised by treating the fixed cells with Alexa Fluor ${ }^{\mathbb{B}}$ 480-conjugated phalloidin dye (1:100 in PBS, 20 minutes), after initial incubation with bovine serum albumin (10mg. $\mathrm{ml}^{-1}$ in PBS one hour) - in order to block all non-specific 
sites. Cultures were counterstained with propidium iodide $\left(10 \mathrm{mg} \cdot \mathrm{ml}^{-1}\right)$ for cell nuclei labelling, for ten minutes. Labelled cultures were mounted in Vectashield ${ }^{\mathbb{B}}$ and examined with a Leica SP2 AOBS (Leica Microsystems) microscopy.

\section{Results and discussions}

\subsection{Physical and morphological analysis of ZnO glass, Zn-GRHA and HA materials}

Based on the glass composition and glass amount added to HA, the final concentration of zinc in the Zn-GRHA material prepared was $0.4 \%$. The range of zinc concentration for an optimal biological response is supposed to be very narrow as previously reported [24]. Figure 1 shows the EDX analysis of zinc glass material. Despite the EDX detection of zinc in the prepared glass, when observing the microstructure of the Zn-GRHA material, the zinc element was not detected. This was due to the fact that the Zn-GRHA material contains only $2.5 \%(\mathrm{~m} / \mathrm{m})$ of $\mathrm{ZnO}$ glass.

Figure 1 EDX analysis of $10 \mathrm{ZnO}-60 \mathrm{P}_{2} \mathrm{O}_{5}-15 \mathrm{CaO}-5 \mathrm{Na}_{2} \mathrm{O}-10 \mathrm{CaF}_{2}$ glass (see online version for colours)

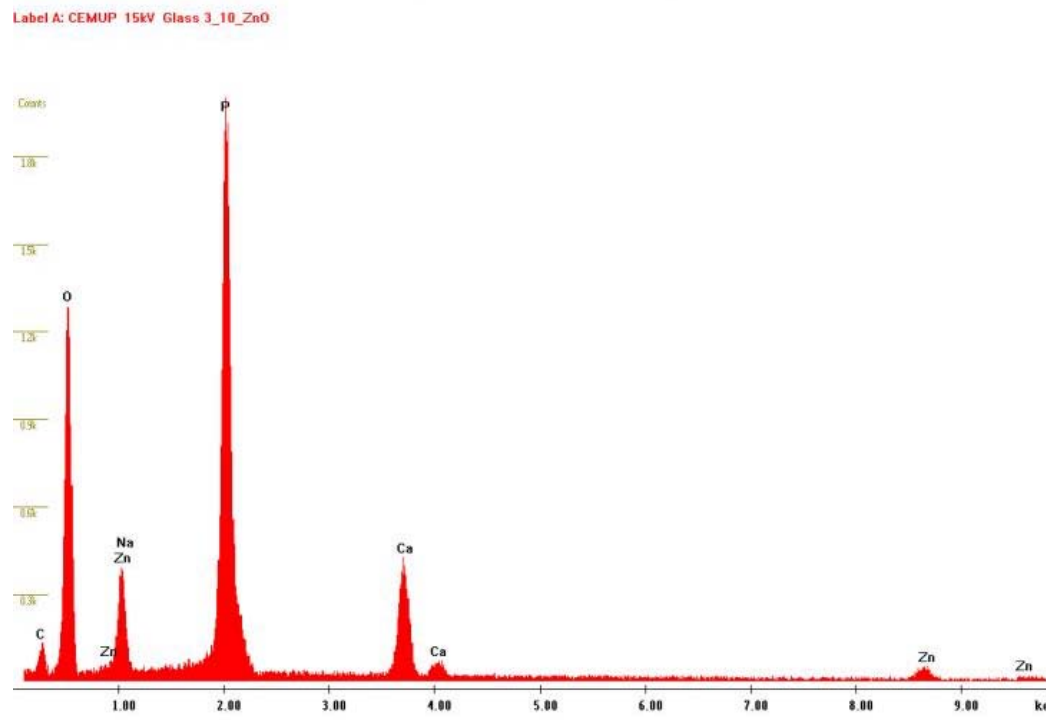

Figure 2 shows the XRD of hydroxyapatite powder produced, which shows that the material is pure phase HA. The XRD of Zn-GRHA composite is shown in Figure 3. From this diffractogram, the following three phases can be identified: $\mathrm{HA}, \mathrm{Ca}_{10}\left(\mathrm{PO}_{4}\right)_{6}(\mathrm{OH})_{2}, \beta$ and $\alpha$-TCP, $\mathrm{Ca}_{3}\left(\mathrm{PO}_{4}\right)_{2}$. No zinc containing phases were detected. It means that the zinc ions should be incorporated in the lattice structure of HA or TCP phases. Further, Rietveld analysis of the XRD spectrum obtained should be done to confirm this incorporation by quantifying the lattice parameters and the distortion index. 
Figure 2 XRD of HA material

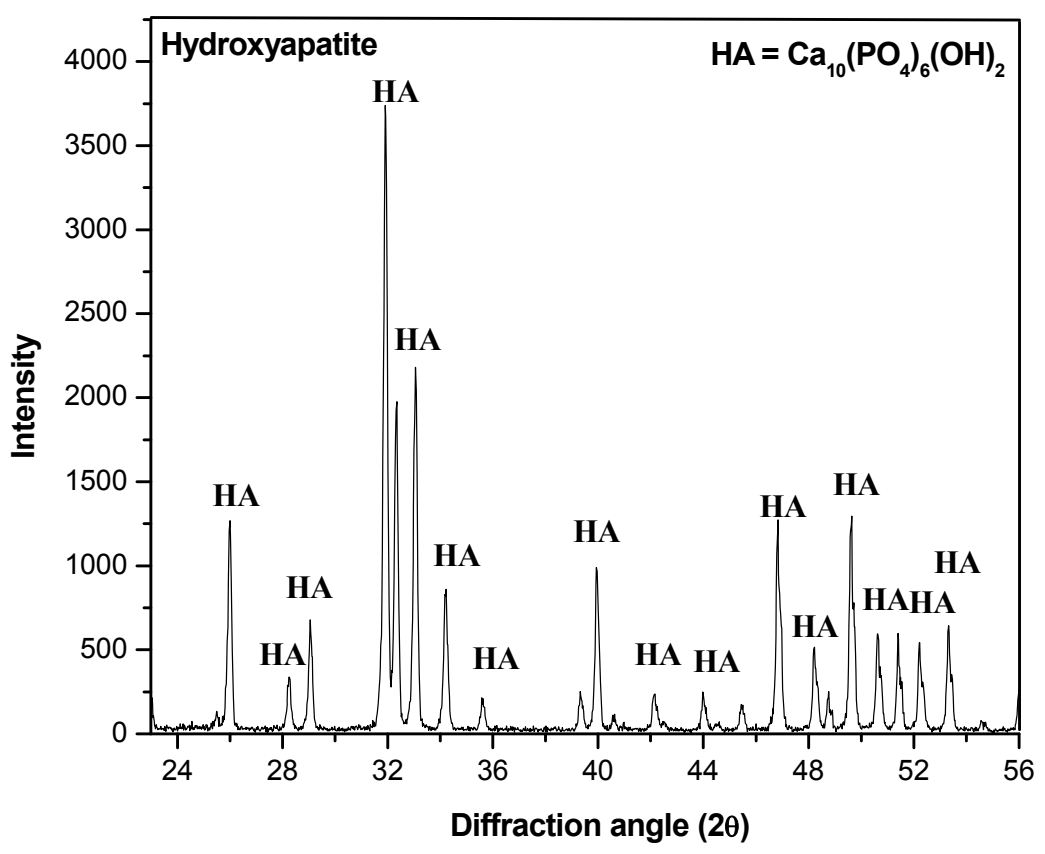

Figure 3 XRD of zinc glass reinforced hydroxyapatite (Zn-GRHA) material

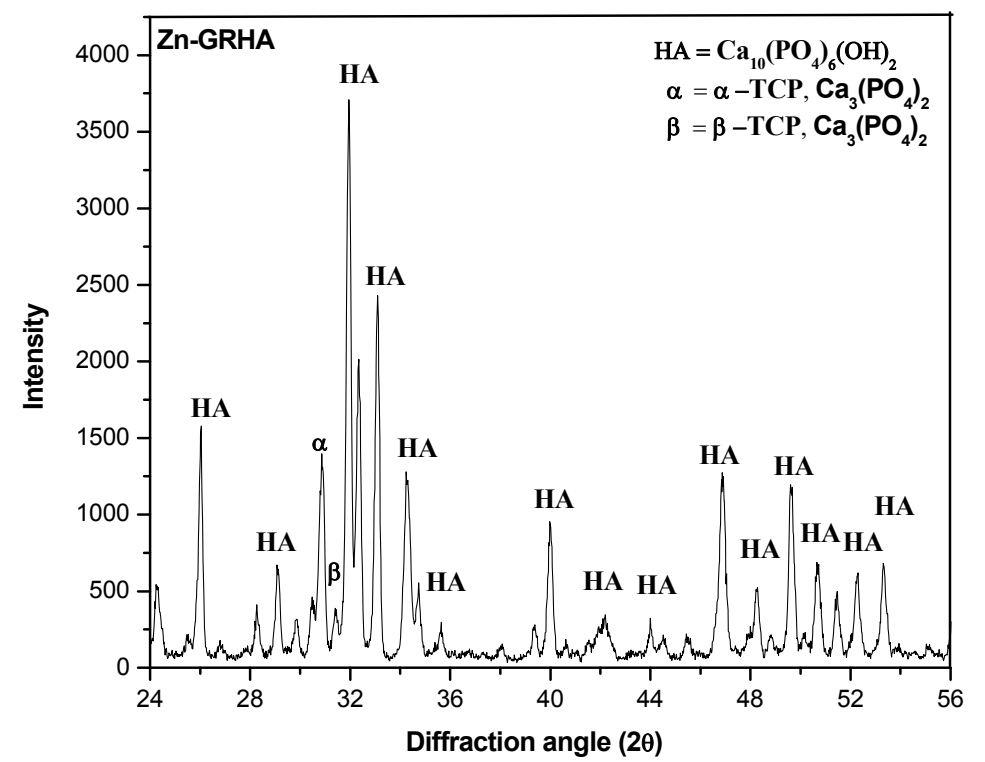

The presence of TCP phases in the composition of the Zn-GRHA were expected, since previous studies of these authors have already demonstrated that the liquid sintering process that occurs due to the presence of a glass in the sintering process of HA leads to the reaction of HA with a glass and therefore part of it is converted into TCP phases. 
SEM observation of the surface of Zn-GRHA and HA materials have shown that both materials are almost fully dense materials.

\subsection{Colonisation of Zn-GRHA and HA with MG63 cells}

Biological behaviour of Zn-GRHA and HA samples was assessed by CLSM, as shown in Figure 4. CLSM images of seeded Zn-GRHA samples at day two [Figure 4(a)] showed that the material surface was colonised with MG63 cells, reporting already areas of high cell density. Cells proliferated actively with culture time and at day six the material surface was completely covered by dense multiple cell layers [Figure 4(c)]. Comparatively, the number of cells that attached to HA samples was significantly lower, both at days two and six [Figure 4(b) and (d)]. On both materials, cells displayed a normal morphology, with cytoplasmic flattening and spreading, prominent nucleus, numerous filipodia and extensive cell-to-cell contact, as evident at a higher magnification, as shown in Figure 5. These observations regarding the enhanced osteoblast adhesion and proliferation on Zn-GRHA samples are in line with previous in vitro studies performed on various $\mathrm{Zn}$-containing substrates, namely $\mathrm{Zn}(2 \%)$-doped HA (Fujita et al., 2003), Zn-organoapatite coating (Storrie and Stupp, 2005), Zn-releasing calcium phosphate ceramics (Ikeuchi et al., 2003) and Zn-phosphate-based glasses (Salih et al., 2007).

Figure 4 CLSM images of Zn-GRHA and HA samples cultured with MG63 cells for two and six days (see online version for colours)

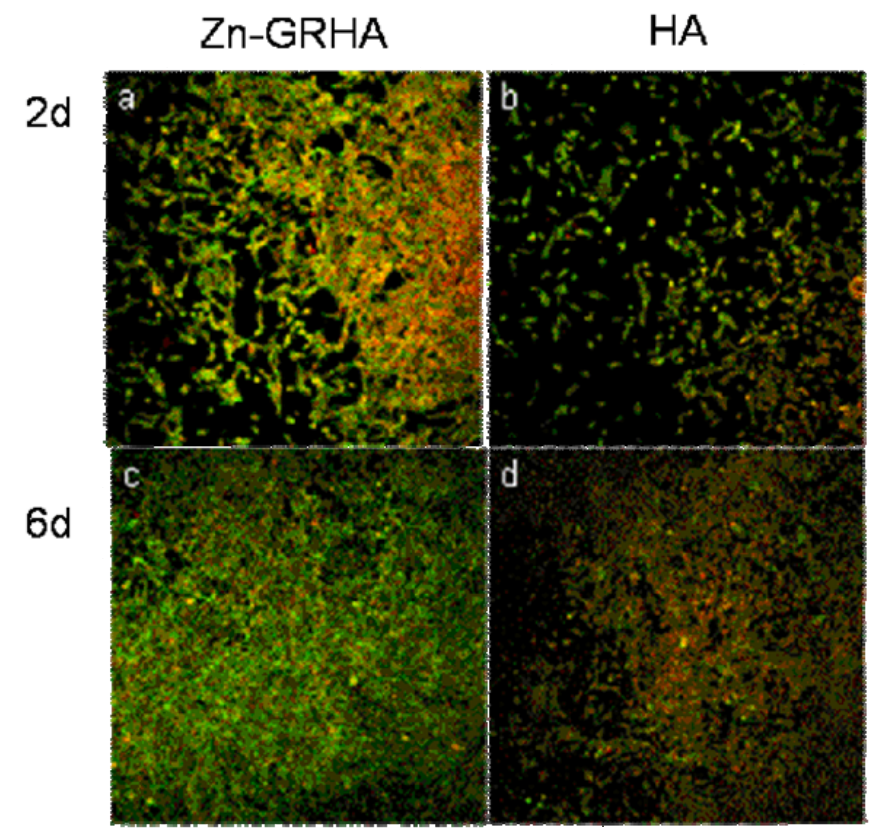


Figure 5 High magnification CLSM images of Zn-GRHA and HA samples cultured with MG63 cells for two days (see online version for colours)

Zn-GRHA

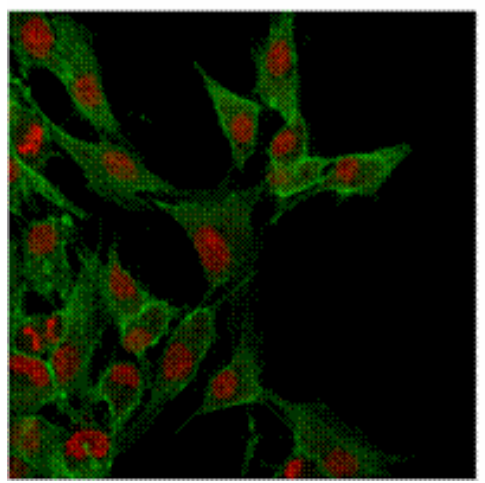

HA

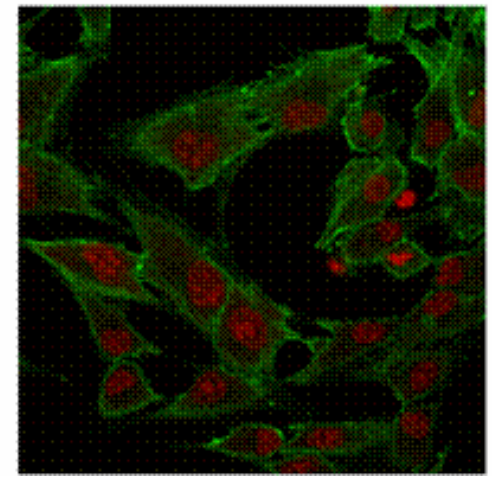

Zinc is an essential trace element, usually a cofactor in metalloenzymes and proteins. Alkaline phosphatase, which is involved in the mineralisation of the colagenous bone matrix, is a Zn-metalloenzyme (Yoon et al., 1989). Zinc appears to play a significant role in bone metabolism having stimulatory effects on bone formation in vitro and in vivo (Hall et al., 1999; Kawamura et al., 2003), as well as an inhibitory effect on osteoclastic bone resorption in vitro (Moonga and Dempster, 1995). Also zinc has been reported to have an antibacterial effect when added to glass-ionomer-based cements (Osinaga et al., 2003) and ceramic coatings (Bright et al., 2002) - a useful property in decreasing bone infection risk associated with the repair of skeletal defects.

\section{Conclusions}

This paper reports preliminary results of the potential impact of zinc-glass reinforced hydroxyapatite (Zn-GRHA) on osteoblastic cell behaviour. Regarding biological evaluation by CLSM, an increased cell number was verified in the Zn-GRHA materials, compared to pure phase HA. Accordingly, at six days of culture, multiple cell layers were visualised on the surface of this material. Hence, the partially addition of zinc may provide the Zn-GRHA system with appropriate biodegradation as well as the enhancement of bone formation. Therefore, further in vitro and in vivo studies are underway to assess the osteoblastic response by using Zn-GRHA material.

\section{References}

Bright, R.R., Gerba, C.P. and Rusin, P.A. (2002) 'Rapid reduction of Staphylococcus aureus populations on stainless steel surfaces by zeolite coatings containing silver and zinc ions', J. Hosp. Infect., Vol. 52, pp.307-309.

Caria, P.H.F., Kawachi, E.Y., Bertran, C.A. and Camilli, J.A. (2007) 'Biological assessment of porous - implant hydroxyapatite combined with periosteal grafting in maxillary defects', J. Oral and Maxillofaci. Surg., Vol. 65, No. 5, pp.847-854. 
Clasans-Maia, M., Fernandes, G.V.O., Rossi, A., Dias, E.P., Almeida, G.D.S., Mitri, F.F. and Granjeiro, J.M. (2008) 'Effect of hydroxyapatite and zinc-containing hydroxyapatite on osseous repair of critical size defects in the rat Calvaria', Key Eng. Mater., Vols. 361-363, pp.1273-1276.

Fujii, E., Ohkubo, M., Tsuru, K., Hayakawa, S., Osaka, A., Kawabata, K., Bonhomme, C. and Babonneau, F. (2006) 'Selective protein adsorption property and characterization of nano - crystalline zinc-containing hydroxyapatite', Acta Biomaterialia, Vol. 2, pp.69-74.

Fujita, R., Yokoyama, A., Kawasaki, T. and Takao, K. (2003) 'Bone augmentation osteogenesis using hydroxyapatite and $\beta$-tricalcium phosphate blocks', J. Oral Maxillofaci. Surg., Vol. 61, No. 9, pp.1045-1053.

Gutierres, M., Dias, A.G., Lopes, M.A., Sooraj Hussain, N., Cabral, A.T., Almeida, L. and Santos, J.D. (2007) 'Opening wedge high tibial osteotomy using 3D biomodelling Bonelike ${ }^{\circledR}$ macroporous structures - case report', J. Mater. Sci.: Mat. Med., Vol. 18, pp.2377-2382.

Gutierres, M., Lopes, M.A., Sooraj Hussain, N., Lemos, A.F., Ferreira, J.M.F., Afonso, A., Cabral, A.T., Almeida, L. and Santos, J.D. (2008) 'Bone ingrowth in macroporous Bonelike ${ }^{\circledR}$ for orthopaedic applications', Acta Biomaterilia, Vol.4, No. 2, pp.370-377.

Hall, S.L., Dimai, H.P. and Farley, J.R (1999) 'Effects of zinc on human skeletal alkaline phosphatise activity in vitro', Calcif Tissue Int., Vol. 64, pp.163-172.

Hing, K.A., Wilson, L.F. and Buckland, T. (2007) 'Comparative performance of three ceramic bone graft substitutes', The Spine J., Vol. 7, No. 4, pp.475-490.

Hussain, N.S., Lopes, M.A., Fernandes, M.H., Ali, N. and Santos, J.D. (2007) 'Bonelike ${ }^{\circledR}$ graft for bone regenerative applications', in Jackson, M.J. and Ahmed, W. (Eds.): Surface Engineered Surgical Tools and Medical Devices, Chapter 13, pp.477-512, Springer Publisher.

Ikeuchi, M., Ito, A., Dohi, Y., Ohgushi, H., Shimaoka, H., Yonemasu, K. and Tateishi, T. (2003) 'Osteogenic differentiation of cultured rat anh human bone marrow cells on the surface of zinc-releasing calcium phosphate ceramics', J. Biomed. Mat. Res., Vol. 67A, pp.1115-1122.

Jaroch, D.B. and Clupper, D.C. (2007) 'Modulation of zinc release from bioactive sol-gel derived $\mathrm{SiO}_{2}-\mathrm{CaO}-\mathrm{ZnO}$ glasses and ceramics', J. Biomed. Mater. Res., Vol. 82A, pp.575-588.

Kawamura, H., Ito, A., Miyakawa, S., Layrolle, P., Ojima, K., Ichinose, N. and Tateishi, T. (2002) 'Stimulatory effect of zinc-releasing calcium phosphate implant on bone formation in rabbit femora', J. Biomed. Mater. Res., Vol. 50, pp.184-190.

Kawamura, H., Ito, A., Muramatsu, T., Miyakawa, S., Ochiai, N. and Tateishi, T. (2003) 'Long term implantation of zinc-releasing calcium phosphate ceramics in rabbit femora', J. Biomed. Mater. Res., Vol. 65A, pp.468-474.

Knowles, J.C., Talal, S. and Santos, J.D. (1996) 'Sintering effects in a glass reinforced hydroxyapatite', Biomaterials, Vol. 17, pp.1437-1442.

Moonga, B.S. and Dempster, D.W. (1995) 'Zinc is a potent inhibitor of osteoclastic bone resorption in vitro', J. Bone Miner. Res., Vol. 10, pp.453-457.

Okuda, T., Ioku, K., Yonezawa, I., Minagi, H., Kawachi, G., Gonda, Y., Murayama, H., Shibata, Y., Minami, S., Kamihira, S., Kurosawa, H. and Ikeda, T. (2007) 'The effect of the microstructure of $\beta$-tricalcium phosphate on the metabolism of subsequently formed bone tissue', Biomaterials, Vol. 28, No. 16, pp.2612-2621.

Osinaga, P.W.R., Grande, R.H.M., Ballester, R.Y., Simionato, M.R.L., Rodrigues, C.R.M.D. and Muench, A. (2003) 'Zinc sulfate addition to glass-ionomer - based cements: influence on physical and antibacterial properties, zinc and fluoride release', Dent. Mater., Vol. 19, pp.212-217.

Otsuka, M., Marunaka, S., Matsuda, Y., Ito, A., Layrolle, P. and Naito, H. (2000) 'Calcium level responsive in-vitro zinc release from zinc containing tricalcium phosphate (ZnTCP)', J. Biomed. Mater. Res., Vol. 52, pp.819-824.

Prasad, A.S. (1998) 'Zinc in human health: an update', J. Trace Elem. Exp. Med., Vol. 11, pp.63-87. 
Prasad, A.S. (2000) 'Effects of zinc deficiency on immune functions', J. Trace Elem. Exp. Med., Vol. 13, pp.1-20.

Prasad, A.S., Bao, B., Beck, F.W.J., Omer, K. and Sarkar, F.H. (2004) 'Antioxidant effect of zinc in humans', Free Radical Biology and Medicine, Vol. 37, No. 8, pp.1182-1190.

Rush, S.M. (2005) 'Bone graft substitutes: Osteobiologics', Clin. in Podiatric Med. Surg., Vol. 22, No. 4, pp.619-630.

Salih, V., Patel, A. and Knowles, J.C. (2007) 'Zinc containing phosphate-based glasses for tissue engineering', Biomed. Mater., Vol. 2, pp.11-20.

Santos, J.D., Hastings, G.W. and Knowles, J.C. (1999) 'Sintered hydroxyapatite compositions and method for the preparation thereof', Worldwide Applications (PCT), Patent No. 1189851.

Santos, J.D., Reis, R.L., Knowles, J.C., Monteiro, F.J. and Hastings, G.W. (1995) 'Liquid phase sintering of hydroxyapatite by phosphate and silicate glass additions. Structure and properties of the composites', J. Mater. Sci.: Mater. Med., Vol. 6, pp.448-452.

Silva, R.V., Camilli, J.A., Bertran, C.A. and Moreira, N.H. (2005) 'The use of hydroxyapatite and autogenous cancellous bone grafts to repair bone defects in rats', Int. J. Oral and Maxillofaci. Surg., Vol. 34, No. 2, pp.178-184.

Sopyan, I., Mel, M., Ramesh, S. and Khalid, K.A. (2007) 'Porous hydroxyapatite for artificial bone applications', Sci. Technol. of Adv. Mater., Vol. 8, Nos. 1-2, pp.116-123.

Spadaro, J.A., Becker, R.O. and Bachman, C.H. (1970) 'The distribution of trace metal ions in bone and tendon', Calc. Tiss. Res., Vol. 6, pp.49-54.

Storrie, H. and Stupp, S.I. (2005) 'Cellular response to zinc-containing organoapatite: an in vitro study of proliferation, alkaline phosphatise activity and biomineralization', Biomaterials, Vol. 26, pp.5492-5499.

Uckan, D., Cin, S., Dincer, N.F., Yalcin, S. and Cavdar, A. (2001) 'Oral zinc tolerance test in pregnant women', J. Trace Elem. Exp. Med., Vol. 14, pp.17-23.

Wang, Z.L. (2004) 'Nanostructures of zinc oxide', Mater. Today, Vol. 7, No. 6, pp.26-33.

Walsh, W.R., Vizesi, F., Michael, D., Auld, J., Langdown, A., Oliver, R., Yu, Y., Irie, H. and Bruce, W. (2008) ' $\beta$-TCP bone graft substitutes in a bilateral rabbit tibial defect model', Biomaterials, Vol. 29, No. 3, pp.266-271.

Webster, T.J., Ergun, C., Doremus, R.H. and Bizios, R. (2002) 'Hydroxyapatite with substituted magnesium, zinc, cadmium and yttrium II. Mechanisms of osteoblast adhesion', J. Biomed. Mater. Res., Vol. 59, pp.312-317.

Weinand, C., Pomerantseva, I., Neville, C.M., Gupta, R., Eli, W., Madisch, I., Shapiro, F., Abukawa, H., Troulis, M.J. and Vacanti, J.P. (2006) 'Hydrogel- $\beta$-TCP scaffolds and stem cells for tissue engineering bone', Bone, Vol. 38, No. 4, pp.555-563.

Yoon, K., Golub, E. and Rodan, G.A. (1989) 'Alkaline phosphatase cDNA transfected cells promote calcium and phosphate deposition', Connect Tissue Res., Vol. 22, pp.17-25. 